\title{
A NEW TRUSTEESHIP FOR WORLD PEACE AND SECURITY: CAN AN OLD LEAGUE OF NATIONS IDEA BE APPLIED TO A TWENTY-FIRST CENTURY IRAQ?
}

\author{
Brian Deiwert*
}

\section{INTRODUCTION:}

On May 1, 2003, U.S. President George W. Bush declared that "major combat operations in Iraq" had ended. ${ }^{1}$ The United States led coalition, which included the United Kingdom, Australia, and Poland, now had the task of rebuilding a devastated Iraq and administrating a defeated country until the Iraqi people "establish a [new] government of, by and for the Iraqi people."2 The coalition would "stay until our work is done and then we will leave and we will leave behind a free Iraq." 3 The coalition, labeled by the United Nations Secretary Kofi Annan ${ }^{4}$ on March 28, 2003, as occupying powers under the Fourth Geneva Convention of 1949, Relative to the Protection of Civilian Persons in Persons in Time of $\mathrm{War}^{5}$ had assumed "responsibilities, and obligations under applicable international law," or a de-facto trusteeship over Iraq. ${ }^{6}$

* J.D., Indiana University School of Law - Indianapolis, 2005 (expected); B.A. in Psychology, Purdue University, 1994. The author thanks Professor William C. Bradford for his assistance with the topic. The author also thanks Rosa T. Neal, Sara MacLaughlin, Marie Castetter, David Root, and Rebecca L. Woodard for their numerous edits and suggestions of this Note.

1. President George W. Bush, Address on U.S.S. Abraham Lincoln (May 1, 2003), available at http://www.whitehouse.gov/news/releases/2003/05/iraq/20030501-15.html (last visited Mar. 8, 2004) [hereinafter Abraham Lincoln].

2. Id.

3. Id.

4. See The Columbia Encyclopedia, 6th ed. (2001), available at http://www.bartleby .com/65/un/UN.html (last visited Mar. 8, 2004). Established in 1945, it is an international organization composed of currently 191 nations. See id. The purposes of the United Nations are "the maintenance of international peace and security; the development of friendly relations among states; and the achievement of cooperation in solving international economic, social, cultural, and humanitarian problems. It also expresses a strong hope for the equality of all people and the expression of basic freedoms." Id. Kofi Annan was elected as U.N. Secretary in 1997. See id.

5. See Wikipedia: The Free Encyclopedia 2003 Iraq War Timeline, available at http://en.wikipedia.org/wiki/2003_Iraq_war_timeline (last visited Mar. 8, 2004).

6. Convention Relative to the Protection of Civilian Persons in Time of War, Aug. 12, 1949, 6 UST 3516, 75 UNTS 287. 
The use of territorial trusteeships ${ }^{7}$ or trusteeship-like arrangements has increased over the years. ${ }^{8}$ Politicians, editorialists, and legal experts have called for trusteeships of the Palestinian territories, ${ }^{9}$ Cambodia, ${ }^{10}$ East Timor, ${ }^{11}$ Kosovo, ${ }^{12}$ Liberia, ${ }^{13}$ Bosnia, ${ }^{14}$ and now Iraq. ${ }^{15}$ It has been suggested the United Nations can "help the United States bear the burdens of lone-superpower status" 16 by reactivating "one of the world body's most vital organs,"17 the U.N. Trusteeship Council. ${ }^{18}$

7. See The Columbia Encyclopedia, 6th ed. (2001), available at http://www.bartleby .com/65/tr/trustees.html (last visited Feb. 16, 2004) [hereinafter Trusteeship]. The territorial trusteeship was a "system of UN control for territories that were not self-governing." Id. "[T] he trusteeship system was intended to promote the welfare of the native inhabitants and to advance them toward self-government." Id.

8. See generally TOM PARKER, CENTRE For EUROPEAN AND ASIAN STUdiEs AT NORWEGIAN SCHOOLOFMANAGEMENT, THE ULTIMATE INTERVENTION: REVITALISING THE UN TRUSTEESHIP COUNCIL FOR THE 21ST CENTURY (2003).

9. See Suzanne Nossel, A Trustee For Crippled States, WASH. Post, Aug. 25, 2003, at A17. See also Martin Indyk, A U.S.-Led Trusteeship For Palestine, WASH. Post, June 29, 2002, at A23.

10. See Nossel, supra note 9. Cambodia is a country located in Southeast Asia. The Columbia Encyclopedia, 6th ed. (2001), available at http://www.bartleby.com/65/ca/Cambodia.html (last visited Mar. 8, 2004). Cambodia is bordered by Vietnam to the east, by Laos to the north, by the Gulf of Thailand to the south, and by Thailand on the west and north. See id.

11. See Nossel, supra note 9. East Timor occupies the eastern half of the island Timor located at the eastern end of the Indonesian archipelago in South East Asia. See CIA - World Factbook-East Timor, at http://www.cia.gov/cia/publications/factbook/geos/tt.html (last visited Mar. 8, 2004) [hereinafter East Timor]. East Timor is northwest of Australia. Id.

12. See Nossel, supra note 9. Kosovo is a Serbian province in the former Yugoslavia in Southeast Europe. See The Columbia Encyclopedia, 6th ed. (2001), at http://www.bartleby .com/65/ko/Kosovo.html (last visited Mar. 8, 2004).

13. See Nossel, supra note 9. Liberia is a west African country with the Atlantic Ocean forming the southwestern border and Guinea on the northern border. See The Columbia Encyclopedia, 6th ed. (2001), at http://www.bartleby.com/65/li/Liberia.html (last visited Feb. $16,2004)$.

14. See Henry Kissinger, Toward a Moment of Truth in Bosnia, WASH. POST, July 11, 1995, at C07. Bosnia is located on the Balkan peninsula in southern Europe. See The Columbia Encyclopedia, 6th ed. (2001), at http://www.bartleby.com/65/bo/BosniaNH.html (last visited Mar. 8, 2004). The Bosnians voted for independence from Yugoslavia in October, 1991. See id.

15. See Paul Kennedy, UN Trusteeship Council Could Finally Find a Role in Postwar Iraq, May 9, 2003, available at http:/www.globalpolicy.org/security/issues/iraq/after/2003/ 0511 trusteeshipcouncil.htm (last visited Mar. 8,, 2004). See also Michael McFaul, Wrong Time to 'Stay the Course', WASH. Post, Aug. 24, 2003, at B07. See also Nossel, supra note 9.

16. Nossel, supra note 9.

17. Id.

18. See PARKER, supra note 8, at 3. The U.N. Trusteeship Council was set up to promote the welfare of native inhabitants in territories that were not self-governing. See Trusteeship, supra note 7. Membership in the Trusteeship Council included those nations administering trust territories, other members of the U.N. Security Council that were not administering trust territories, and as many member nations elected to the Council as needed to ensure the total number of members on the Trusteeship Council were equally divided between those countries administering trust territories and those not administering trust territories. U.N. CHARTER art. 86. 
If the Trusteeship Council were revived to assist the United States in Iraq administration, what difference would it make? Could the United States "still remain in day-to-day control . . . but [with] overall supervisory authority . . stay[ing] with the U.N.,"19 while granting easier access to international organizations that can assist in the redevelopment of Iraq, such as the World Bank, the U.N. Development Program, UNICEF, and the World Health Organization? $?^{20}$ This Note attempts to answer the question of whether a nation-state that has been militarily intervened, such as Iraq, can be placed under a U.N. trusteeship until the native population is capable of governing themselves. Additionally, this Note addresses what legal problems could arise from an attempt to revive the Trusteeship Council, and how can such problems be resolved?

Part I of this Note explains the historical context of the trusteeship. Part II discusses the elements of a trusteeship. Then Part III analyzes the recent challenges faced by the international community where the Trusteeship Council could have been of assistance. Part IV analyzes the legal problems confronting a revival of the trusteeship process. Finally, Part $\mathrm{V}$ discusses how Iraq could benefit from a revival of the Trusteeship Council.

\section{PART I. HISTORICAL BACKGROUND ON TRUSTEESHIP}

\section{A) Origins Of The Trust Concept}

The discovery of the New World by European explorers allowed legal theorists of the day to raise the issue of a trusteeship. ${ }^{21}$ Those theorists "argued that the New World should be developed in the interests of its native peoples and not just for the profit of Spaniards."22 The trusteeship concept developed more explicitly during the British colonial and expansion era. ${ }^{23}$ The Eighteenth Century British politician Edmund Burke is widely credited as being the first to invoke the concept of 'trust' during his speeches that addressed British policy in India and North America; and he "coined the phrase 'sacred trust' which appears in Article 22(1) of the Covenant of the League of Nations and Article 73 of the UN Charter." ${ }^{24}$ That philosophy eventually permeated British Imperial thinking. ${ }^{25}$ In 1898, the British were acting as "trustees of civilisation for the commerce of the world," 26 according

19. Stephen Handelman, U.N. as Colonial Power? Why not?, TORONTO STAR, Sept. 2 , 2003, at A17.

20. Kennedy, supra note 15.

21. See PARKER, supra note 8, at 3 - 4. Mr. Parker states those first legal theorists were Jean Lopez de Palacios Rubios and Franciscus de Vitoria. Id. at 3.

22. PARKER, supra note 8 , at 4 .

23. See id.

24. Id.

25. See id.

26. Id. 
to the British Colonial Secretary Joseph Chamberlain. ${ }^{27}$ Other European countries along with the United States also explored the concept of trusteeship during the Nineteenth Century. ${ }^{28}$ Fifteen European nations produced the "General Act which bound the signatories to "care for the improvement of the conditions of the moral and material well-being' of the natives of the Congo Basin"29 at the Berlin Conference of 1884-1885. ${ }^{30}$

The trusteeship concept "took on an added dimension . . . of international accountability" ${ }^{31}$ at the beginning of the Twentieth Century. ${ }^{32}$ The outbreak of World War I in $1914^{33}$ caused a shift in attitude as the trusteeship concept became linked with "plans to create an international body to regulate and oversee international affairs." ${ }^{34}$ The U.S. President Woodrow Wilson, ${ }^{35}$ captured this idea in his Fourteen Points for peace address on January 8, 1918. ${ }^{36}$ Two points in particular stand out. First, Point V which proclaimed,

[a] free, open-minded, and absolutely impartial adjustment of all colonial claims, based upon a strict observance of the principle that in determining all such questions of sovereignty the interests of the populations concerned must have equal weight with the equitable claims of the government whose title is to be determined. ${ }^{37}$

Second, Point XIV which stated, "[a] general association of nations must be formed under specific covenants for the purpose of affording mutual

27. PARKER, supra note 8, at 4. Joseph Chamberlain served as Colonial Secretary of the British Conservative government from 1895 to 1903. See The Columbia Encyclopedia, 6th ed. (2001), available at http://www.bartleby.com/65/ch/ChamberlJos.html (last visited Mar. 8, 2004). He "pursued a vigorous colonial policy aimed at imperial expansion, cooperation, and consolidation." Id.

28. See PARKER, supra note 8 , at 4.

29. Id. at $4-5$.

30. Id. at 4. The Berlin Conference settled the problems of having colonies in west Africa that the European countries were experiencing. See The Columbia Encyclopedia, 6th ed. (2001), available at http://www.bartleby.com/65/be/BerlinConf.html (last visited Mar. 8, 2004). Members of the Berlin Conference were all European nations, the United States, and the Ottoman Empire. See id.

31. PARKER, supra note 8, at 5.

32. See id.

33. See Margaret MacMillan, Paris 1919, Six Months That Changed The World 89 (2001), xxv.

34. PARKER, supra note 8 , at 5.

35. See The Columbia Encyclopedia, 6th ed. (2001), available at http://www.bartleby.com/65/wi/Wilson-W.html (last visited Feb. 16, 2004). Woodrow Wilson was the 28th President of the United States and served from 1913-21. See id.

36. See President Woodrow Wilson, Address to Joint Session of Congress (Jan. 8, 1918), available at http://usinfo.state.gov/usa/infousa/facts/democrac/51.htm (last visited on Mar. 8, 2004). 
guarantees of political independence and territorial integrity to great and small states alike." 38

In December 1918, the South African soldier-statesman General Jan Smuts took President Wilson's ideas and released a paper titled "The League of Nations: A Practical Suggestion." 39 General Smuts suggested the colonial territories belonging to Austria, Russia, and Turkey should be administrated by the victorious nations of the war under a mandate of the League of Nations. ${ }^{40}$

\section{B) The League Of Nations Mandate System}

The Paris Peace Conference ${ }^{41}$ established a Commission on the League of Nations which was chaired by President Wilson on January 25, 1919.42 The issue of mandates proved to be the most contentious item on the agenda. ${ }^{43}$ President Wilson's views prevailed over other dignitaries in Article 22 of the Covenant of the League of Nations. ${ }^{44}$ The colonies of Turkey and Germany that were "inhabited by peoples not yet able to stand by themselves under the strenuous conditions of the modern world" 45 were placed under the mandate system. ${ }^{46}$ However, President Wilson had to compromise with France, South Africa, Australia, and New Zealand whose delegates favored annexation. ${ }^{47}$ General Smuts helped craft a compromise which created a three-tiered Mandates System. ${ }^{48}$ ' $A$ ' class mandates were for nations, such as those in the Middle East, nearly ready to be independent. ${ }^{49}$ ' $\mathrm{B}$ ' class mandates were for territories that would be run by the mandatory power, and ' $C$ ' class mandates

38. $I d$.

39. See MACMILLAN, supra note 33, at 89.

40. See PARKER, supra note 8, at 6 . The League of Nations was established by the Treaty of Versailles and other peace treaties ending World War I in order to promote international peace and security. See The Columbia Encyclopedia, 6th ed. (2001), available at http://www .bartleby.com/65/le/LeagueNa.html (last visited Mar. 8, 2004) [hereinafter League].

41. See MACMILLAN, supra note 33, at xxv - xxxvi. The Paris Peace Conference of 1919 -20 was the attempt to end World War I. See id. The most well-know result of the conference is the Treaty of Versailles ending Germany's involvement in the war signed in June 1919. See id.

42. See PARKER, supra note 8 , at 6.

43. See id. Mandates were the system of administrative trusteeships of the former German colonies and Turkish territories established by the League of Nations after World War 1. See League, supra note 40 . The mandate power, the administrator of the mandated territory or mandatory, had assumed obligations to the inhabitants of the territory and to the League of Nations, which supervised the mandates through the eleven members of the Permanent Mandates Commission. See id.

44. See PARKER, supra note 8 , at 6.

45. LEAGUE OF NATIONS COVENANT art. 22, para. 1., available at http://www.yale.edu/ lawweb/avalon/leagcov.htm (last visited Mar. 8, 2004).

46. See PARKER, supra note 8, at 7.

47. See id.

48. See MACMILLAN, supra note 33, at 103.

49. See id. 
were created for "territories contiguous or close to the mandatory power which would be run as an extension of its own territory subject to certain restrictions." 50

In spite of the colonial powers wrangling, Article 22 of the League of Nations Covenant still had most of President Wilson's vision of trusteeship. ${ }^{51}$ The Mandate System was to apply "the principle that the well-being and development of such peoples form a sacred trust of civili[z]ation and that securities for the performance of this trust should be embodied in [the League Covenant]." 52 To give effect to that principle "the tutelage of such peoples should be entrusted to advanced nations ... who are willing to accept [such responsibility] ... on behalf of the League." ${ }^{53}$ International supervision was accomplished under Article 22(7) where "the Mandatory shall render to the Council an annual report in reference to the territory committed to its charge." " 54 " $\mathrm{A}]$ body of practice and precedent relating to international oversight" ${ }^{\text {"55 }}$ was created for the administration of territories. ${ }^{56}$

In 1920, fourteen former Turkish and German territories that contained approximately 20 million people were placed under mandate. 57 "Three ' $A$ ' class mandates ... (Iraq, Syria-Lebanon and Palestine), six 'B' class mandates were carved out of ... Togoland-Cameroons and German East Africa and five ' $C$ ' class Mandates created from former German colonies in South West Africa and the Pacific." 58

The Mandate System had flaws. ${ }^{59}$ First, the Permanent Mandates Commission could do little more than publicly condemn blatant breaches of Trusteeship by the Mandatory Powers. ${ }^{60}$ Second, "the manner in which the administration of the ' $\mathrm{B}$ ' and ' $\mathrm{C}$ ' class mandates was approached looked very similar in consequence to direct annexation." ${ }^{\prime 1}$ Despite these flaws, when the Mandate System was abolished in 1946, both Iraq and Syria-Lebanon had achieved independence. ${ }^{62}$

50. PARKER, supra note 8, at 7. See also MACMILLAN, supra note 33, at 103.

51. See PARKER, supra note 8 , at 7.

52. LEAGUE OF NATIONS COVENANT art. 22, para. 1.

53. LEAGUE OF NATIONS COVENANT art. 22, para. 2.

54. LEAGUE OF NATIONS COVENANT art. 22, para. 7.

55. PARKER, supra note 8 , at 9.

56. See id.

57. See id. at 8.

58. Id.

59. See id. at $8-9$

60. See id. at 8-9.

61. PARKER, supra note 8 , at 8 .

62. See id. Lebanon became an independent country in 1943; however, French troops did not leave until 1946. See Wikipedia, The Free Encyclopedia, available at http://en. wikipedia.org/wiki/1948_Arab-Israeli_War (last visited Mar 8, 2004). Syria became independent on April 17,1946 from France when French troops evacuated and left Syria in the hands of a republican government formed during the period of French Mandate. See Wikipedia, The Free Encyclopedia, available at http://en.wikipedia.org/wiki/History_of_Syria (last visited Mar. 8, 2004). Iraq achieved independence from the British Mandate in 1932. See Wikipedia, 


\section{C) The International Trusteeship System Of The United Nations.}

After World War II, the creation of the United Nations allowed the international community "to address the shortcomings that had become apparent in the Mandates System." ${ }^{\text {"33 }}$ The international climate had changed considerably; now the practice of colonialism was "under fire from all sides."

In August 1941, both the British Prime Minister Winston Churchill and the U.S. President Franklin D. Roosevelt publicly stated in a joint declaration known as the Atlantic Charter that they would respect the right of all people to choose the form of government they wished to live under. ${ }^{65}$ The colonial territories started to develop independence movements. ${ }^{66}$ Colonial commitment to the Allied ${ }^{67}$ cause had been brought, in part, with promises of change. ${ }^{68}$ The myth of European invincibility had been devastated by Japan's initial military success against the colonies of the European colonial powers. ${ }^{69}$ Some European nations had lost the will to continue as colonial powers due to the war or occupation. ${ }^{70}$ The public attitude had shifted away from colonial aspirations. $^{71}$

The idea of an International Trusteeship System was discussed at the Yalta Conference in February $1945 .^{72}$ At the insistence of Winston Churchill

The Free Encyclopedia, available at http://en.wikipedia.org/wiki//raq (last visited on Mar. 8, 2004).

63. PARKER, supra note 8 , at 9.

64. $1 d$. (citing THE UNITEd NATIONS AT THE MILLENIUM: THE PRINCIPAL ORGANS 142 (Paul Graham Taylor \& A.J.R. Groom eds., 2000)).

65. See id. President Roosevelt and Prime Minister Churchill meet "in Argentina Bay, off Newfoundland to issue a joint declaration on the purposes of the war against fascism." The Atlantic Charter (1941), at http://usinfo.state.gov/usa/infousa/facts/democrac/53.htm (last visited Mar. 8, 2004). The joint declaration was issued on August 12, 1941. See Hyperwar: The Atlantic Charter, at http://www.ibiblio.org/hyperwar/Dip/Atlantic.html (last visited Mar. 8, 2004).

66. See PARKER, supra note 8 , at 10.

67. See The Columbia Encyclopedia, 6th ed. (2001), available at http://www.bartleby .com/65/ww/WW2.html (last visited Mar. 8, 2004)[hereinafter WWII]. The Allies were the victorious powers of World War II that fought against the Axis Powers of Germany, Italy, and Japan. See id.

68. See PARKER, supra note 8 , at 10.

69. See id. Japan initially conquered Malaya, Burma, and the Netherlands East Indies. See WWII, supra note 67.

70. See PARKER, supra note 8, at 10.

71. Id.

72. See id. (citing R. Chowdhuri, International Mandates and Trusteeship Systems: A Comparative Study, at 18 (1955)). The Yalta Conference was one of a series of conferences held by the United States, United Kingdom, and the U.S.S.R. during World War II. See Wikipedia, The Free Encyclopedia, available at http://en.wikipedia.org/wiki/Yalta_Conference (copy on file with author). The conference was held from February 4-11, 1945. See id. Among the ideas discussed was the creation of the United Nations to replace the League of Nations, the dismemberment of Germany, and the U.S.S.R.'s entry into the war against Japan when Germany was defeated. See id. 
and French General Charles de Gaulle, there would to be no discussions of the territories to be affected by the new trusteeship system at the upcoming San Francisco Conference where the United Nations Charter would be created. ${ }^{73}$

Like the previous Mandates System of the Paris Peace Conference, the International Trusteeship System "became one of the most contentious issues of the [San Francisco] [C]onference" due to the need to find compromise. ${ }^{74}$ States' experience with the Mandates System led to the implicit ideas in the sparsely worded League Covenant being transformed into the detailed text of The International Trusteeship System in the United Nations Charter. ${ }^{75}$

The International Trusteeship System was spelled out in great detail in Chapters XII and XIII of the U.N. Charter. ${ }^{76}$ Issues of trusteeship were distinguished from issues of colonial administration. ${ }^{77}$ The later issues formed Chapter XI entitled Declaration Regarding Non-Self-Governing Territories. ${ }^{78}$ Among the changes Chapter XII imposed, was a far more detailed set of obligations for the Administering States to fulfill and the Trusteeship Territories had "more sophisticated [legal] personality than under the League Covenant."79 "The Charter also identified the promotion of political, economic, social and educational development towards self-government as one of the System's principle objectives. ${ }^{80}$ The lackadaisical practices of the Mandates System were thrown out with the explicitly stated purposes of the new International Trusteeship System. ${ }^{81}$

The main differences from the previous Mandates System consisted of substantial changes in the security, the oversight system, and the economic relationship between the Trusteeship Territory and the Administering Power were. ${ }^{82}$ The Trusteeship Council was a principal organ of the United Nations along with the Security Council, General Assembly, and the International Court of Justice. ${ }^{83}$ Rather than composing of private citizens that was typical under the mandate Commission, the Trusteeship Council was to be composed

73. See PARKER, supra note 8, at 10. The San Francisco Conference to create the United Nations charter began on April 25, 1945. See Wikipedia, The Free Encyclopedia, available at http://en.wikipedia.org/wiki/United_Nations (last visited Mar. 8, 2004). The fifty nations at the conference signed the charter on June 26, 1945 and the United Nations came into existence on October 24, 1945. See id.

74. See PARKER, supra note 8 , at $10-11$.

75. See id. at 11 (citing H. Duncan Hall, Mandates, Dependencies and Trusteeships, 277 (1948)).

76. See generally U.N. CHARTER art. $75-91$.

77. See PARKER, supra note 8, at 11.

78. See id.

79. See id. (citing A. Anghie, The Heart of My Home: Colonialism, Environmental Damage and the Naure Case, 34 Harv. Int. L. J. 454-55 (1993)).

80. Id. See also U.N. CHARTER art. 76, para. 1(b).

81. See PARKER, supra note 8, at 11.

82. See id.

83. See U.N. CHARTER art. 7, para. 1. An Economic and Social Council and the Secretariat were the other principle organs listed. See id. 
of government representatives that could be "backed by the full authority of his or her government" ${ }^{\prime 4}$ The Council membership was to be evenly divided among administering members and non-administering members. ${ }^{85}$ The ultimate authority concerning Trusteeship matters was the General Assembly. ${ }^{86}$

The new trusteeship system also echoed the post-war concerns of security and defense. ${ }^{87}$ The Administrating Powers were obligated to provide for and assist the Trust Territories in maintaining "international peace and security." 88 Chapter XII created the concept of Special Strategic Areas ${ }^{89}$ allowing the U.N. Security Council to place all or part of a Trust Territory under its jurisdiction. ${ }^{90}$ The importance of this unusual clause became very clear as the United States established a string of military bases in the Pacific using that exemption. ${ }^{91}$

The League of Nations dissolved on April 18, 1946, and with that the Mandates System terminated. ${ }^{92}$ The majority of the Mandates were voluntarily submitted to the new Trusteeship System. ${ }^{93}$ The goal of the Trusteeship Council was "to give the Trust Territories full statehood."94 After the last trusteeship, Palau, ${ }^{95}$ attained statehood in December 1994, the Trusteeship Council suspended operation with a claim that it had succeeded in its duty. ${ }^{96}$

84. PARKER, supra note 8, at 11 (citing H. Duncan Hall, Mandates, Dependencies and Trusteeships, 278 (1948)).

85. See U.N. CHARTER art. 86, para. 1. Administering members had trust territories to administrate while non-administering members had no trust territories to administer. See generally id.

86. See id. at art. 85, para. 1.

87. See PARKER, supra note 8, at 11 .

88. Id. See also U.N. CHARTER art. 76, para. 1(a).

89. See id. at art. 82, para. 1.

90. See id. at art. 82. para. 1.

91. See PARKER, supra note 8, at 11-12.

92. See id.

93. See id. at 12. Eleven territories were placed under the Trusteeship System. See id. at 25 .

94. Id. at 12. Comment made by U.N. Secretary General Trygve Lie to the Trusteeship Council's first session on March 26, 1947. See id.

95. See Wikipedia: The Free Encyclopedia, available at http://en.wikipedia.org/wiki/ Palau (last visited on Mar. 8, 2004). Palau was granted independence on October 1, 1994. Palau is a tropical island nation in the Pacific Ocean located $500 \mathrm{~km}$ east of the Philippines. See id. Spain colonized the islands during the late 1800 's. See id. Germany purchased the islands in 1899; however, Japan seized them during World War I. See id. Japan obtained a Mandate from the League of Nations and held the islands until the end of World War II. See id. The islands were controlled as a Trust Territory of the United States under the United Nations. See id. The citizens of Palau elected to have independence instead of joining the Federated States of Micronesia; independence was official in 1994. See Wikipedia: The Free Encyclopedia, available at http://en.wikipedia.org/wiki/Palau (last visited on Mar. 8, 2004). Palau maintains relations with the United States under a Compact of Free Association, which states the United States will provide for military defense for the island nation for 50 years. See Wikipedia: The Free Encyclopedia, available at http://en.wikipedia.org/wiki/Foreign_relations_of_Palau (last visited on Mar. 8, 2004).

96. See PARKER, supra note 8, at 12. 


\section{D) International Territorial Administration}

The International Trusteeship System and the Mandates System were not the only programs that allowed for the stewardship of so-called undeveloped peoples. ${ }^{97}$ An "ad-hoc device for the international stewardship of peoples and territory" 98 termed "international territorial administration"99 should be noted as well. International Territorial Administration [hereinafter ITA] often operated in conjunction with, or as an alternative to, the system of mandates and trusteeships. ${ }^{100}$ The overlap of state practice in administering other territories, whether by mandate/trusteeship or ITA, ${ }^{101}$ requires an analysis of the ITA as it has evolved over time, especially in conjunction with the mandate/trusteeship concept. ${ }^{102}$ A common denominator among all International Territorial Administrations was the "desire to impose order on chaos and help territories and peoples no longer in a position to help themselves." 103 This desire is at the core of the trusteeship concept. ${ }^{104}$

The term, territorial administration, "refers to a formally constituted, locally based management structure operating with respect to a particular territorial unit; it can be limited (e.g., a territorial program concerned with certain matters [such as distribution of medicine or electoral monitoring]) or plenary (e.g., a territorial government) in scope." 105 The right to "either ... supervise and control the operation of this structure by local actors, or to operate the structure directly" is asserted by an international organization. ${ }^{106}$ This right "can pertain to the structure as a whole, or certain parts of it (e.g., the legislature)", and is exercised by the international organization within the territory. ${ }^{107}$

ITA, as a device, is used "to replace local actors [from administrating], either partly or fully, because of two perceived problems with the 'normal' model [of administration in the territory]." 108 The perceived problems of local administration include: 1), "a perceived sovereignty problem with the presence of local actors exercising control over the territory[;]"109 and 2), "a perceived governance problem with the conduct of governance by local

97. See id.

98. Id.

99. Ralph Wilde, From Danzig to East Timor and Beyond: The Role of International Territorial Administration, 95 AM. J. INT'L L. 583, 584-85 (2001).

100. See id. at 602-03.

101. See id. at 604.

102. See PARKER, supra note 8, at 12.

103. Id.

104. See id.

105. Wilde, supra note 99 , at 585.

106. See id.

107. See id.

108. Id. at 587.

109. Wilde, supra note 99 , at 587. 
actors." 110 "The first problem concerns the identity of the local actors being excluded from administration; the second problem concerns the quality of governance being exercised in the territory."111

\section{i.) International Territorial Administration prior to World War I.}

The Treaty of Paris of $1856^{112}$ can be said to be the historical origin of the ITA. ${ }^{113}$ That treaty established the European Danube Commission for the purpose of restoring lower reaches of the Danube River to a navigable state. ${ }^{114}$ The Commission consisted of seven countries including Great Britain, France, Austria, Prussia, Russia, Sardinia and Turkey. ${ }^{115}$ As the Commission successfully completed its duties, it was given new powers, including the power "to levy charges, effect public works and regulate river traffic." 116 By World War I, the Commission operated in complete independence of territorial authority, and its personnel and works were accorded neutral status. ${ }^{117}$

Another pre-League of Nations manifestation of ITA was created by the International Sanitary Convention of 1892 , which established the International Sanitary Councils. ${ }^{118}$ For many decades, the successful operation of the Sanitary Councils in Constantinople, Alexandria, and Tangier helped prevent the spread of infectious diseases. ${ }^{119}$ These Councils are noted to "constitute an early humanitarian challenge to the concept of absolute state sovereignty."120

The outbreak of World War I ruined a promising pre-League of Nations experiment in ITA concerning the Spitzbergen Archipelago. ${ }^{121}$ Located in the Artic Ocean, the Spitzbergen Archipelago was "considered terra nullius of

110. Id.

111. Id.

112. Treaty of Paris, Mar. 30, 1856, 114 Parry's T.S. 409. See also The Columbia Encyclopedia, 6th ed. (2001), available at http://www.bartleby.com/65/pa/Paris-Co.html (last visited Mar. 8, 2004). The Treaty of Paris of 1856 negotiated the peace after the Crimean War between France, Great Britain, the Ottoman Empire, Sardinia, Russia, Austria, and Prussia. See id.

113. See PARKER, supra note 8, at 12.

114. See id. at 12-13.

115. See id. at 12.

116. Id. at 13 .

117. See id. An internationally recognized flag even flew over the European Danube Commission's establishments. See id.

118. See PARKER, supra note 8, at 13.

119. See id.

120. Id.

121. See id. The Spitzbergen Archipelago appears to be currently named Svalbard with Spitzbergen being the largest island. See Wikipedia: The Free Encyclopedia, available at http://en.wikipedia.org/wiki/Spitzbergen (last visited Mar. 8, 2004). The islands are located at Seventy-Eight degrees north latitude and Twenty degrees west longitude in the Artic Ocean and are approximately the size of the state of West Virginia. See CIA - The World Factbook Svalbard, available at http://www.cia.gov/cia/publications/factbook/print/sv.html (last visited Feb. 16, 2004) (copy on file with author) [hereinafter Svalbard]. 
little or no value until the discovery of workable coal deposits in 1900," which prompted interest from Norway, Sweden, and Russia. ${ }^{122}$ The three countries drafted a convention creating a neutral Spitzbergen open to all nationalities in 1912. ${ }^{123}$ The draft convention was never ratified due to the start of World War I; however, the draft "became the blueprint for subsequent 'free city' proposals." "124 In 1920, Norway's sovereignty was recognized; it took over the territory in $1925 .{ }^{125}$

While the above examples of direct international territorial administration were largely successful, most attempts at ITA failed and gave the drafters of the League of Nations Covenant a negative impression of the ITA concept. ${ }^{126}$ These failures included an attempt to create an International Police Force in the Sultanate of Morocco, ${ }^{127}$ and the Albanian International Commission of Control. ${ }^{128}$ In 1919, these failures provided President Wilson's opponents at the Paris Peace Conference with ample reason to reject Wilson's idea of writing the principle of direct international administration into the League Covenant. ${ }^{129}$

\section{ii.) International Territorial Administration between the World Wars.}

The absence of the principle of direct international administration in the League Covenant was not an obstacle for the League to press the concept "into service as a convenient solution to a variety of disparate problems during the inter-war years." 130 The League first exercised ITA in the Free City of Danzig, where the League "possessed certain governmental rights between

122. See PARKER, supra note 8, at 13.

123. See id.

124. Id.

125. See Svalbard, supra note 121. At the Paris Peace Conference of 1919, the option of putting Spitzbergen under the Mandates System was discussed. See PARKER, supra note 8, at 13.

126. See PARKER, supra note 8 , at 13.

127. See id. at 14. The International Police was created at the Algeciras Conference of 1906 to maintain order and relieve rising tensions between the European, mostly French, residents and the local population. See id. The idea behind the International Police was to suppress unrest in the Sultanate of Morocco in order to deprive France of a reason to occupy Morocco. See id. It failed in 1911 when France occupied Morocco. See id.

128. See PARKER, supra note 8, at 13. The Albanian Commission of Control began operations in October 1913 to shepherd the Albanians toward independence after the Ottoman Turk administration left. See id. The European powers offered the Commission little support and did not send troops to impose order in the chaotic Albanian territory. See id. at 14. When World War I broke out in July 1914, the Commission members withdrew, leaving Albanian on its own. See id. Austria occupied Albania in 1916 after a year and a half of anarchy in the territory. See id.

129. See id.

130. PARKER, supra note 8 , at 15 . 
1920 and 1939."131 To establish a permanent solution to competing Polish and German claims to the city, the Treaty of Versailles ${ }^{132}$ created the Free City. ${ }^{133}$ Poland enjoyed authority over certain domestic issues as well as foreign policy. ${ }^{134}$ Danzig itself was self-administered, however, the League was empowered "to ensure that the city's 'free' status was not imperiled by the local administration," "135 and "to settle disputes between the [F]ree [C]ity and Poland." 136

The League also administered the German Saar Basin between 1920 and 1935. ${ }^{137}$ Under the Treaty of Versailles, France was entitled to reparations from Germany by exploitation of mines located in the Saar region for fifteen years. ${ }^{138}$ France had desired to annex the Saar outright, but those efforts were thwarted during negotiations at the Paris Peace Conference. ${ }^{139}$ In light of France's desire of the Saar, French administrative control was seen as problematic. ${ }^{140}$ The solution was to have the League administrate the Saar during the fifteen year period of reparations, after "which the citizens of the Saar would be given the opportunity to choose between union with France, union with Germany or remaining under League control."141 With respect to sovereignty claims, the League was seen as neutral. ${ }^{142}$ The interests of both Germany and France were protected by the League and allowed the two countries to address the issue of the Saar in a less hostile atmosphere. ${ }^{143}$

131. Wilde, supra note 99, at 586. See also PARKER, supra note 8, at 15 . Danzig was an ethnically German city on the Baltic coast in the German state of West Prussia. See United States Holocaust Memorial Museum, at http://www.ushmm.org/wlc/article.php?ModuleID $=10005438$ (last visited Oct. 29, 2003)(copy on file with author). After World War I, the Treaty of Versailles required Germany to cede West Prussia to the new state of Poland. See id. After World War II, the Danzig was acquired by Poland, the ethnic Germans expelled or fled, and the city was renamed Gdansk. See id.

132. Treaty of Versailles, June 28, 1919. See The Columbia Encyclopedia, 6th ed. (2001), available at http://www.bartleby.com/65/ve/VersaillTr.html (last visited Mar. 8, 2004). The Treaty of Versailles was the most important among the five peace treaties that ended World War I. See id. It was signed on June 28,1919 by Germany and the countries that fought against Germany save Russia. See id.

133. See PARKER, supra note 8, at 15.

134. See Wilde, supra note 99 , at 596.

135. PARKER, supra note 8, at 15. See also Wilde, supra note 99, at 596.

136. Wilde, supra note 99 , at 596.

137. See id. at 586. See also PARKER, supra note 8, at 15 . The Saar is bordered by France in the south and west and Luxembourg in the northwest. See The Columbia Encyclopedia, Sixth Ed. (2001), available at http://www.bartleby.com/65/sa/Saarland.html (last visited Mar. 8, 2004) [hereinafter Saarland].

138. See Wilde, supra note 99 , at 589. See also PARKER, supra note 8 , at 15 . The Saar has extensive coal mines. See Saarland, supra note 137.

139. See PARKER, supra note 8, at 15.

140. See Wilde, supra note 99, at 589. See also PARKER, supra note 8, at 15.

141. PARKER, supra note 8 , at 15.

142. See Wilde, supra note 99 , at 589.

143. See PARKER, supra note 8, at 15. 
League administration was successfully dissolved in 1935, when the residents of Saar voted for union with Germany. ${ }^{144}$

More significant development of the ITA principle occurred in 1933 when Peruvian irregulars invaded and occupied the Colombian border town of Leticia. ${ }^{145}$ Peru, while claiming no responsibility for the attack, promised to come to the irregulars' aid if Columbian forces attempted to retake the border town. ${ }^{146}$ Tensions along the border were high as the League's assistance was sought to resolve the crisis. ${ }^{147}$ The solution reached was plenary administration of Leticia by the League in the name of Columbian government for one year, accompanied by withdrawal of the Peruvian irregulars. ${ }^{148}$ Columbia was responsible for the League Commission's expenses and administrative costs along with providing troops for the Commission's security. ${ }^{149}$

The mission features reflected that it was common acceptance that Leticia was part of Colombia. ${ }^{150}$ "[F]or Colombia the League's intervention simply facilitated the peaceful hand-over of control of [Leticia] to its forces." 151 Peru agreed to the League solution because it provided "that the territory would [be held in trust and] not be transferred to Colombia until the wider border dispute between the two countries was resolved." 152 The League ITA allowed Leticia to be shielded from further conflict as Peru and Colombia negotiated on all other outstanding issues. ${ }^{153}$ Upon the creation of a border agreement that resolved the issues, only then could control of Leticia be transferred back to Columbia. ${ }^{154}$

Though invited by the disputants to assist in the resolution of their border conflict, the League set precedent by intervening on its own initiative to place the sovereignty of a territory in dispute within its own powers. ${ }^{155}$ This is in contrast to the League's administration of the Saar, due to authority being granted to the League by the Treaty of Versailles. ${ }^{156}$

\section{iii.) International Territorial Administration during the Cold War.}

After World War II, the idea of international cooperation and performing as a group of united nations was fashionable, especially among minor

144. See id.

145. See Wilde, supra note 99 , at 588. See also PARKER, supra note 8 , at 15.

146. See Wilde, supra note 99 , at 588.

147. See PARKER, supra note 8 , at 15.

148. See Wilde, supra note 99 , at 588.

149. See id. See also PARKER, supra note 8 , at 15.

150. See Wilde, supra note 99 , at 588.

151. PARKER, supra note 8 , at 15.

152. Wilde, supra note 99 , at 588.

153. See id.

154. See id.

155. See PARKER, supra note 8 , at 16.

156. See id. 
states. ${ }^{157}$ President Wilson's idea for direct international government was crafted into Article 81 of the United Nations Charter, which identified the United Nations as a potential Administering Authority within the International Trusteeship System. ${ }^{158}$ These factors allowed the possibility of "a considerably more proactive international organi[z]ation than the League." 159

An ITA was set up with the United Nations as a potential Administering Authority for Libya; thereby, promoting the ideals behind Article 81 in a setting outside of the International Trusteeship System. ${ }^{160}$ In 1947, the victorious Allied countries of World War II were empowered to decide the status of Libya, a former Italian colony. ${ }^{161}$ The Allies passed the issue to the United Nations General Assembly, who then appointed a United Nations Commissioner for Libya whose duties were to prepare the territory for independence. ${ }^{162}$ Two other Administrating Powers, France and Britain, in conjunction with the United Nations, administered Libya until independence in $1951 .{ }^{163}$

Early in the United Nations' life, other experiments in ITA were crafted, but never implemented for one reason or another. ${ }^{164}$ The U.N. General Assembly adopted a resolution for the international administration of the City of Jerusalem in November 1947. ${ }^{165}$ Upon British withdrawal from the Mandate of Palestine, two independent states, one Jewish and one Arab, were to be created with the U.N. Trusteeship Council administrating Jerusalem no later than October $1,1948 .{ }^{166}$ The General Assembly delegated to the Trusteeship Council powers clearly not identified in the U.N. Charter. ${ }^{167}$ The 1948 war between Israel and Jordan halted the implementation of this plan. ${ }^{168}$ It should be noted that "more than two-thirds of the votes cast in the General Assembly [favored] the plan underlined the willingness of the Member States right from the outset to consider using the Trusteeship Council for tasks outside those explicitly stated in the Charter."169

157. See id.

158. See id. Article 81 reads, "The trusteeship agreement shall in each case include the terms under which the trust territory will be administered and designate the authority which will exercise the administration of the trust territory. Such authority, hereinafter called the administering authority, may be one or more states or the Organization itself." U.N. CHARTER art. 81

159. PARKER, supra note 8 , at 16.

160. See id.

161. See id.

162. See id.

163. See id.

164. See generally PARKER, supra note 8, 16-20.

165. See G.A. Res. 181(II), U.N. GAOR, 2nd Sess, U.N. Doc. A/516 (1947).

166. See id.

167. See PARKER, supra note 8, at 16-17.

168. See id. at 17.

169. Id. 
Another failure in international territorial administration, "the refusal of South Africa to place its former class ' $C$ ' Mandate South West Africa under the International Trusteeship System[,]"significantly impacted the development of international law. ${ }^{170}$ The International Court of Justice (ICJ) issued four advisory opinions and two judgments on this issue over the next thirty years when South Africa attempted to annex South West Africa after the dissolution of the League of Nations and its Mandates system in 1946. ${ }^{171}$

In 1950, the first advisory opinion issued by the ICJ considered whether or not South Africa was obligated to place South West Africa under the U.N. Trusteeship System. ${ }^{172}$ The Court reasoned that a Mandate was not required to be placed in the Trusteeship System; however, South Africa could not unilaterally alter the international status of South West Africa either. ${ }^{173}$ The Court noted that despite the dissolution of the League of Nations "those powers of supervision now belong to the General Assembly of the United Nations." 174

Two further advisory opinions issued by the ICJ concerned the manner in which supervisory powers could be exercised by the General Assembly. ${ }^{175}$ In 1956, "the ICJ found that the General Assembly's Committee on South West Africa could grant oral hearings to petitioners despite [the] fact that the League Council had never actually exercised this right."176 South Africa continued to ignore the Court's opinions. ${ }^{177}$

In 1966, South Africa successfully contested the jurisdiction of the ICJ in the case of South West Africa (Ethiopia v. South Africa: Liberia v. South Africa). ${ }^{178}$ The Court's judgment that Ethiopia and Liberia could not enforce rights that did not belong to them so enraged the developing countries that redress was sought through the U.N. General Assembly. ${ }^{179}$

170. See id.

171. See id. at 17-19.

172. See International Status of South-West Africa, 1950 I.C.J 128 (July 11).

173. See PARKER, supra note 8, at 17. See also International Status of South-West Africa, 1950 I.C.J. 128 (July 11 ).

174. International Status of South-West Africa, 1950 I.C.J 128, at 141 (July 11).

175. See PARKER, supra note 8, at 17. See also International Court of Justice: List of all Decisions and Advisory Opinions Brought Before the Court Since 1946, at http://www.lawschool.cornell.edu/library/cijwww/icjwww/idecisions.htm (last visited Mar. 8, 2004). The two advisory opinions are Voting Procedure on Questions Relating to Reports and Petitions Concerning the Territory of South-West Africa, 1955 I.C.J. 67 (June 7) and Admissibility of Hearings of Petitioners by the Committee on South-West Africa, 1956 I.C.J. 23 (June 1). See id.

176. PARKER, supra note 8, at 17. See also Admissibility of Hearings of Petitioners by the Committee on South-West Africa, 1956 I.C.J. 23 (June 1).

177. See PARKER, supra note 8, at 17.

178. See South West Africa (Ethiopia v. South Africa: Liberia v. South Africa), 1966 I.C.J. 6 (July 18).

179. See PARKER, supra note 8, at 18. 
In October 1966, the General Assembly cancelled South Africa's Mandate and placed South West Africa under United Nations' responsibility. ${ }^{180}$ The General Assembly created the United Nations Council for South West Africa to administrate the former Mandate by Resolution 2248; however, South Africa refused to accept the withdrawal of its mandatory power, and refused the Council's entry into the territory. ${ }^{181}$

The last advisory opinion issued by the ICJ in 1971 concerning South West Africa, ${ }^{182}$ (since renamed Namibia) concluded the U.N. General Assembly was the legal successor to the League's supervisory powers and it lawfully terminated South Africa's Mandate. ${ }^{183}$ It was not until 1988 that South Africa finally agreed to Namibian independence; at that time the only administrative role exercised by the United Nations was to supervise and control the local elections. ${ }^{184}$

Though the territory never became the subject of an ITA, the General Assembly clearly intended that it should have been. ${ }^{185} \mathrm{~A}$ bright side to the failure of the South West Africa situation is that a strong body of law developed concerning "a number of key aspects of the Trusteeship System including its overall purpose, the powers invested in the General Assembly and the accountability of Administering Authorities."186

The United Nations made "one more substantive attempt during the Cold War period to exercise sole executive authority" over a disputed territory, Irian Jaya (the western half of the island of New Guinea). ${ }^{187}$ The territory remained under Dutch administration when the rest of the Dutch East Indies gained independence as Indonesia. ${ }^{188}$ By 1960, the Netherlands and Indonesia had such a long running dispute over the territory that "serious consideration" was given to a Malaysian proposal to create a trusteeship under the joint supervision of Malaysia, Netherlands, and Australia. ${ }^{189}$ The proposal received Dutch approval; however, the Indonesians saw that independence was the logical end of a U.N. trusteeship and subsequently rejected the proposal. ${ }^{190}$

180. See id. The General Assembly's actions cancelled the Mandate. See G.A. Res. 2145 , U.N. GAOR, 21 th Sess., Supp. No. 21, U.N. Doc. A/RES/2145 (1966).

181. See PARKER, supra note 8, at 18. See also Wilde, supra note 99, at 592.

182. See Legal Consequences for States of the Continued Presence of South Africa in Namibia (South-West Africa) Notwithstanding Security Council Resolution 276, 1971 I.C.J. 16 (June 21).

183. See PARKER, supra note 8 , at 18 .

184. See Wilde, supra note 99 , at 593. Under U.N. Supervision South African forces withdrew from Namibia in 1990. See also PARKER, supra note 8, at 18.

185. See PARKER, supra note 8 , at 18.

186. Id. at $18-19$.

187. See id. at 19.

188. See Wilde, supra note 99 , at 588.

189. See PARKER, supra note 8 , at 19.

190. See id. 
The U.N performed an ITA for seven months (October 1962 to May 1963) in Irian Jaya to manage the transfer of authority from Dutch colonial authorities to Indonesia. ${ }^{191}$ The U.N. followed up by monitoring a popular vote to determine if the people wished to stay with Indonesia or become independent. ${ }^{192}$

\section{iv.) International Territorial Administration After the Cold War.}

The end of the Cold War was a new dawn for the United Nations in its exercise of authority in significant new ways to address conflicts and resolve the aftermath. ${ }^{193}$ By this time, the U.N. Trusteeship Council had nearly disappeared from the international stage with only one trusteeship left under its supervision. ${ }^{194}$ The Trusteeship Council was regarded as a relic and some suggested it was time to kill off the institution. ${ }^{195}$ The U.N. Security Council was now the rising star on the stage as it was providing the diplomatic leadership for the international community. ${ }^{196}$

The 1991 Agreement on a Comprehensive Political Settlement of the Conflict in Cambodia provided the first major U.N. exercise in governance. ${ }^{197}$ The Cambodian factions delegated various governmental functions to the United Nations Transitional Authority in Cambodia (UNTAC), ${ }^{198}$ including foreign affairs, finance, and defense. ${ }^{199}$ UNTAC was created by the U.N. Security Council. ${ }^{200}$

The former Yugoslavian territories of Eastern Slavonia, Baranja, and Western Slavonia, were placed under U.N administration for two years as a result of the Dayton Peace Accords. ${ }^{201}$ The U.N. ousted a military regime in Haiti that usurped the power of the democratically elected President

191. See Wilde, supra note 99, at 588. See also PARKER, supra note 8, at $19-20$.

192. See Wilde, supra note 99, at 588. See also PARKER, supra note 8, at $19-20$.

193. See Michael J. Matheson, United Nations Governance of Postconflict Societies, 95 AM. J. INT'L. L. 76 (2001).

194. See PARKER, supra note 8 , at 20.

195. See id.

196. See id.

197. See Matheson, supra note 193, at 77.

198. See id.

199. See PARKER, supra note 8, at 20-21.

200. See Matheson, supra note 193, at 77. See also PARKER, supra note 8, at 21.

201. See PARKER, supra note 8 , at 21 . The talks at Dayton, Ohio led to a peace accord between Bosnia, Croatia, and Serbia following the breakup of Yugoslavia. See The Columbia Encyclopedia, 6th ed. (2001), available at http://www.bartleby.com/65/yu/Yugoslav.html (last visited Mar. 8, 2004). 
Aristide. ${ }^{202}$ All of the above missions "embody aspects of international territorial administration." 203

"The U.N. was back in the State-building business with a vengeance ..."204 when it was engaged in the tasks of rebuilding and governing both Kosovo and East Timor in $1999-2000 .^{205}$ The interventions in Kosovo and East Timor have been described "as examples of 'Security Council-Mandated Trusteeship Administration." "206 Some began to look at the star of the Trusteeship Council to see if it could rise again to meet these new challenges. ${ }^{207}$

\section{E) The Principles of Non-Self-Governing Territories}

The U.N. Charter, through Articles 73 and 74, commit member states with colonial possessions or non-self-governing-territories (NSGTs) ${ }^{208}$ to the good stewardship principles proclaimed by the Trusteeship System. ${ }^{209}$ "The first designated NSGTs [by the U.N.] were voluntarily admitted to the U.N. regime." 210 After Spain and Portugal refused to voluntarily comply with Chapter XI of the U.N. Charter, the General Assembly passed Resolution 1541 (XV) of 1960 which allowed a special committee to designate certain territories as NSGTs without the consent of the colonial or occupying power. ${ }^{211}$

\section{PART II: THE PRINCIPLES OF TRUSTEESHIP}

Chapters XII and XIII of the U.N. Charter contain the textual legal framework of the U.N. Trusteeship System. ${ }^{212}$ Combined with the operational practice performed by the Trusteeship System, this section of the Note will

202. See PARKER, supra note 8, at 21 . In 1994, the U.N. authorized the use of force to restore democratic rule to Haiti. See The Columbia Encyclopedia, 6th ed. (2001), available at http://www.bartleby.com/65/ha/Haiti.html (last visited Mar. 8, 2004). As United States forces were about to invade, the Haitian military leaders negotiated an amnesty and allowed President Aristide to return to power on October 15, 1994. See id. By then, United States forces had landed to oversee the transition. See id.

203. PARKER, supra note 8, at 21.

204. Id.

205. See id. See also Matheson, supra note 193, at 78 - 83.

206. PARKER, supra note 8, at 21.

207. See id.

208. See U.N.CHARTER art. 73. Article 73 broadly defines Non-Self-Governing Territories as "territories whose peoples have not yet attained a full measure of self-government ...." See Id.

209. See PARKER, supra note 8 , at 22.

210. See id. The territories voluntarily admitted were administered by Australia, Belgium, France, the Netherlands, New Zealand, the United Kingdom, and the United States. See id.

211. See id.

212. See id. 
analyze the key principles of a trusteeship: positive development, eligibility, consent, accountability, and legal status. ${ }^{213}$

\section{A) Positive Development}

"The core aims of the Trusteeship System are enumerated in Article 76 of the UN Charter as the furtherance of international peace and security; the promotion of political, economic, social and educational advancement; progressive development towards self-government or independence; respect for human rights and equal administration of justice." 214 The Administrating Authorities have the duty to protect and defend the Trust Territories from aggressive external threats and to maintain public order internally to ensure "international peace and security."215 Political advancement towards a democratic government is clearly expressed by "freely expressed wishes of the peoples" in Article 76(b). ${ }^{216}$ The Trusteeship Council has promoted this ideal from the beginning. For example, the Trusteeship Council recommended to the Administering Authorities of Ruanda-Urundi ${ }^{217}$ and Tanganyika ${ }^{218}$ that

213. See PARKER, supra note 8 , at 22 - 30.

214. PARKER, supra note 8 , at 23 . Article 76 of the U.N. Charter states in its entirety: The basic objectives of the trusteeship system, in accordance with the Purposes of the United Nations laid down in Article 1 of the present Charter, shall be:

a. to further international peace and security;

b. to promote the political, economic, social, and educational advancement of the inhabitants of the trust territories, and their progressive development towards self-government or independence as may be appropriate to the particular circumstances of each territory and its peoples and the freely expressed wishes of the peoples concerned, and as may be provided by the terms of each trusteeship agreement;

c. to encourage respect for human rights and for fundamental freedoms for all without distinction as to race, sex, language, or religion, and to encourage recognition of the interdependence of the peoples of the world; and

d. to ensure equal treatment in social, economic, and commercial matters for all Members of the United Nations and their nationals, and also equal treatment for the latter in the administration of justice, without prejudice to the attainment of the foregoing objectives and subject to the provisions of Article 80.

U.N. CHARTER art. 76.

215. PARKER, supra note 8, at 23. See also U.N. CHARTER art. 76(a).

216. U.N. CHARTER art. 76(b).

217. See The Columbia Encyclopedia, 6th ed. (2001), available at http://www.bartleby.com/65/ru/RuandaUr.html (last visited on Mar. 6, 2004). The territory of Ruanda-Urundi is now divided between the central African states of Rwanda and Burundi. See id.

218. See The Columbia Encyclopedia, 6th ed. (2001), available at http://www.bartleby.com/65/ta/Tanzania.html (last visited on Mar. 6, 2004) [hereinafter Tanzania]. In 1964, the African countries of Tanganyika and Zanzibar combined to form modern Tanzania. See id. Tanganyika was originally a British colony, then was transferred to Germany in 1890, and was transferred back as a Mandate to Britain after World War I. See id. Tanganyika was declared an independent nation on December 9, 1961. See id. 
they take immediate steps to transition the population from a tribal system to a modern electoral political system. ${ }^{219}$

In order to be truly politically independent, a territory must have some degree of self-sufficiency and economic independence; however, the Administering Authorities must temper the pursuit of legitimate economic development or else it is simple exploitation of the Trust Territories' resources. ${ }^{220}$ " $[\mathrm{P}]$ rovisions for keeping the land and its natural resources in the hands of the local population" have been included in most Trusteeship Agreements. ${ }^{221}$

Without improvements to social and educational areas, the previously mentioned improvements of political and economic development would be hollow. ${ }^{222}$ Although most Trusteeship Agreements contain few details about these improvements, Administering Authorities often point to successes in this field. ${ }^{223}$ The British note the number of children in school in Tanganyika (modern Tanzania) ${ }^{224}$ rose from 35,000 in 1937 to 400,000 in $1960 .{ }^{225}$ France notes the French Cameroons' figure was 100,000 in 1937 to 370,000 in $1961 .^{226}$ The Trusteeship Agreement for Italian Somaliland was atypically specific in expressing the positive changes expected in social improvement: "slavery and child marriage is to be abolished, the sale of drugs, alcohol and firearms controlled and hospitals built."227

Although improvements concerning social and educational issues are generally vague in Trusteeship Agreements, agreements are more concrete concerning "the promotion of human rights and [other] fundamental freedoms."228 The Administering Authority is to promote "progressive development towards self-government or independence." 229 "[T] "The population of a territory may wish to exercise their right to self-government in one of three ways: independence, local autonomy within a larger association of some kind or even assimilation into a larger sovereign State." 230 The determination as to when a population of the Trust Territory has the right to self-determination proved to be a major sticking point between Trust Territories and the Administrating Powers. ${ }^{231}$ Although the Trusteeship Council only once

219. See PARKER, supra note 8, at 23.

220. See id.

221. Id.

222. See id.

223. See id. at 24.

224. See Tanzania, supra note 218.

225. See PARKER, supra note 8, at 24.

226. See id.

227. Id.

228. Id.

229. U.N. CHARTER art. 76(b).

230. PARKER, supra note 8, at 24.

231. See id. 
applied a time limit on a Trusteeship Agreement, ${ }^{232}$ the practice of the Council shows an expectation that the Trusteeships be concluded at the earliest possible moment. ${ }^{233}$

\section{B) Eligibility}

Article 77 of the U.N. Charter created three categories of territories eligible for placement in the International Trusteeship System. ${ }^{234}$ First, territories which had been placed under the League of Nations Mandates System fell under Article 77(1)(a). ${ }^{235}$ Second, territories formally controlled by the defeated countries of World War II were covered in Article 77(1)(b). ${ }^{236}$ Third, a state could voluntarily place a territory for which it is responsible for administering into the Trusteeship System by the powers of Article 77(1)(c)..$^{237}$ The Trusteeship System had eleven territories placed into $\mathrm{it}$; ${ }^{238}$ "ten were former Mandates of the League of Nations" ${ }^{\text {"239 }}$, and one was a territory detached from a defeated nation of World War $\amalg{ }^{240}$ At this time no territory has been voluntarily placed under the Trusteeship System using Article $77(1)(c) .{ }^{241}$

\section{C) Consent}

The only serious attempt of voluntary placement in the Trusteeship System was made by India by exercising Article $77(1)(c) .{ }^{242}$ The Indian

232. See id. A time limit of ten years was placed on Italian Somaliland. See id.

233. See id.

234. See U.N. CHARTER art. 77(1). Article 77(1) states:

The trusteeship shall apply to such territories in the following categories as may be placed there under by means of trusteeship agreements:

a. territories now held under mandate;

b. territories which may be detached from enemy states as a result of the Second World War; and

c. territories voluntarily placed under the system by states responsible for their administration.

Id.

235. See U.N. CHARTER art. 77(1)(a).

236. See U.N. CHARTER art. 77(1)(b).

237. See U.N. CHARTER art. 77(1)(c).

238. See PARKER, supra note 8, at 25.

239. Id. The ten territories placed into trusteeship under Article $77(1)(a)$ were British Togoland, French Togoland, French Cameroons, British Cameroon, Tanganyika, RuandaUrundi, Western Samoa, Nauru, New Guinea, and the Trust Territory of the Pacific Islands consisting of Micronesia, the Marshall Island, the Northern Mariana Islands and Palau. See Mapping the United Nations with Gender Perspective, at http://www.peacewomen.org/un/ basics/unbeg.html (last visited Mar. 6, 2004). See also Trusteeship, supra note 7.

240. See PARKER, supra note 8, at 25 . The former Italian colony of Somaliland was the one territory placed into trusteeship under Article 77(1)(b). See id. 
delegate to the United Nations "described the International Trusteeship System as: '[t]he surest and quickest means of enabling the peoples of dependent territories to secure self-government or independence.",243 India sponsored a draft resolution to see if any of the states administering dependent territories (colonies) intended to place them in the Trusteeship System, but it ultimately failed to obtain adequate support. ${ }^{244}$ India tried again with a different resolution to "encourag[e] the colonial powers to consider voluntarily placing 'relatively backward' territories and colonies afflicted by racial discrimination under the 'progressive and impartial' supervision of the United Nations." 245 The colonial powers did not respond well to this draft and it was defeated in a General Assembly vote. ${ }^{246}$

Article 79 states "[t]he terms of trusteeship for each territory to be placed under the trusteeship system, including any alteration or amendment, shall be agreed upon by the states directly concerned[,]"247 indicating that the states involved in the trusteeship, either as Trusteeship Territories or Administering Powers, must consent to any changes to the agreement. ${ }^{248}$ Without the consent of a state that is directly concerned in the situation, the international community will not approve a trusteeship. ${ }^{249}$ This was demonstrated when Indonesia objected a Malaysian proposal to place Irian Jaya under a U.N. Trusteeship. . $^{250}$

\section{D) Accountability}

A trilateral relationship exists between the Trust Territory, the Administering Authority/Authorities, and the United Nations acting as the neutral Supervising Authority. ${ }^{251}$ Although the Administering Authority/Authorities has in practice been a State(s), Article 81 allows the United Nations to have a dual role as both Supervisor and Administrator. ${ }^{252}$ Articles 87 and 88 of the U.N. Charter provided the Trusteeship Council with great administrative power to ensure the Administrating Authorities were accountable to the Council and the General Assembly. ${ }^{253}$

243. Id.

244. Id.

245. See PARKER, supra note 8 , at 25.

246. See id. at 25-26.

247. U.N. CHARTER art. 79.

248. See PARKER, supra note 8, at 26.

249. See id.

250. See id.

251. See id.

252. See id. Article 81 states, "The trusteeship agreement shall in each case include the terms under which the trust territory will be administered and designate the authority which will exercise the administration of the trust territory. Such authority, hereinafter called the administering authority, may be one or more states or the Organization itself." U.N. CHARTER art. 81. (Emphasis added)

253. See PARKER, supra note 8, at 26 - 27. 
Article 87(a) provided the Trusteeship Council the ability to receive "reports submitted by the administering authority"254 based upon "a questionnaire on the political, economic, social, and educational advancement of the inhabitants" that the Trusteeship Council formulated itself. ${ }^{255}$ The Administering Authority had to present the results of the questionnaire to the General Assembly via an annual report. ${ }^{256}$

Accountability was further enhanced by Article 87(b) allowing the Trusteeship Council to "accept petitions and examine them in consultation with the administering authority." 257 Inhabitants of the Trust Territories sent both written and oral petitions to the Trusteeship Council to have grievances redressed. ${ }^{258}$

A further enhancement of accountability in the Trusteeships System was provided in Article 87(c) by allowing "periodic [inspection] visits to the respective trust territories at times agreed upon with the administering authority." 259 This increased the accountability that the League of Nations had against the Mandatory Powers, who had successfully resisted the idea of regular inspection visits against them. ${ }^{260}$ The inspection visits had positive effects upon the Trust Territories, including the abolishment of racial discrimination and corporal punishment. ${ }^{261}$

Perhaps the best example of an Administering Authority being held accountable to the Trust Territory and the native population is the Island of Nauru. ${ }^{262}$ The small island had rich phosphate deposits so valuable that Australia, New Zealand, and Britain positioned themselves for control of the island. ${ }^{263}$ After World War II, the trusteeship for the island was awarded to Australia. ${ }^{264}$ To assist in the mining operations, Australia attempted to move

254. U.N. CHARTER art. 87(a).

255. U.N. CHARTER art. 88 . Article 88 states:

The Trusteeship Council shall formulate a questionnaire on the political, economic, social, and educational advancement of the inhabitants of each trust territory, and the administering authority for each trust territory within the competence of the General Assembly shall make an annual report to the General Assembly upon the basis of such questionnaire.

Id.

256. See id.

257. U.N. CHARTER art. 87(b).

258. See PARKER, supra note 8 , at 27 . This was a bit of a change from the Permanent Mandates Commission of the League of Nation which had refused to hear oral petitions. See id.

259. U.N. CHARTER art. 87(c).

260. See PARKER, supra note 8, at 27.

261. See id.

262. See id. Nauru is an island in the slightly south of the equator in the South Pacific Ocean, south of the Marshall Islands. See CIA - The World Factbook - Nauru, at http://www.cia.gov/cia/publications/factbook/geos/nr.html (last visited on Mar. 6, 2004). At twenty-one square kilometers, Nauru is the world's smallest independent republic. See id.

263. See PARKER, supra note 8 , at 27.

264. See id. at 28. 
the population; however, that failed by August $1964 .{ }^{265}$ As a result of the ecological damage caused by the mining operations, the United Nations "General Assembly reaffirmed the "inalienable right of the people of Nauru to self-government and independence' and resolved that Australia should take immediate steps to restore the island 'for habitation by the Nauruan people",.266

In June 1992, the International Court of Justice ruled that it had jurisdiction to hear the Nauru case. ${ }^{267}$ This was the first case where an Administering Authority had an action brought against it by a former Trust Territory. ${ }^{268}$ The people of Nauru sought restitution for having one-third of the island mined out during Australian administration, and failing to rehabilitate the land after mining. ${ }^{269}$ Eventually the case was settled for 107 Million Australian Dollars with 2.5 Million Australian Dollars going to rehabilitation projects for a period of twenty years. ${ }^{270}$

\section{E) Legal Status}

"It has been an assumption of the international political system that states are 'sovereign,' though there was sometimes confusion as to whether sovereignty was a characteristic, an implication, a consequence, or a definition of statehood."271 While it is beyond the scope of this Note to debate the exact nature of sovereignty, its importance to the Trusteeship System cannot be denied. ${ }^{272}$ Where sovereignty resides in the Trusteeship System is a complex problem. ${ }^{273}$

Judge McNair of the International Court of Justice opined in International Status of South West Africa ${ }^{274}$ that "[s]overeignty over a [m]andated [t]erritory is in abeyance."275 Judge McNair stated that when a territory became an independent State "sovereignty will revive and vest in the new state."276 This concept was further expanded by Judge Ammoun in the Advisory Opinion on Namibia when he maintained that, "sovereignty was

265. See id.

266. See id.

267. See Certain Phosphate Lands in Nauru (Nauru v. Australia), 1992 I.C.J. 240 (June 26).

268. See PARKER, supra note 8, at 28.

269. See id.

270. See id. The Compact of Settlement was signed on August 10, 1993. See id.

271. LORI FISLER DAMROSCH ET AL., INTERNATIONAL LAW: CASES AND MATERIALS (4th ed. 2001) at 3.

272. See PARKER, supra note 8, at 29.

273. See id.

274. See International Status of South West Africa, 1950 I.C.J. 128, at 150 (July 11) (separate opinion of Sir Arnold McNair).

275. Id. See also PARKER, supra note 8, at 29.

276. International Status of South West Africa, 1950 I.C.J. 128, at 150 (July 11) (separate opinion of Sir Arnold McNair). 
inherent in every people, including those subject to [a] Mandate, and that in such circumstances sovereignty had simply been temporarily deprived of freedom of expression." $" 277$

Although sovereignty may be temporarily deprived of freedom of expression, the Trust Territories have some international legal personality as "the U.N. Charter brought [those territories] into existence."278 Whatever legal personality the Trust Territories possess, it "is clearly distinct from that of the Administering Power whose authority over the territory is constrained by the terms of the Trusteeship Agreement."279 The Trust Territories do not enjoy the same legal rights as fully sovereign states, such as entering into treaties or becoming members of international conventions. ${ }^{280}$ Yet, "[a]s the ICJ highlighted in its Advisory Opinion on the International Status of South West Africa the indigenous peoples of Trust Territories enjoy passive rights that are not dependent on the bounty of the Administering Authority." ${ }^{281}$ The description given by Judge McNair that the Trusteeship Territories are "a new species of international government" appears to be well founded. ${ }^{282}$

\section{PART III: CONTEMPORARY CHALLENGES OF THE MODERN WORLD}

The United Nations eagerly rid the world of colonialism by providing for the self-determination of peoples around the world. ${ }^{283}$ Before World War II erupted in 1939, "nine colonial powers controlled 150 territories that were inhabited by 650 million people." ${ }^{284}$ By the 1970 s, the colonial empires had all but disappeared. ${ }^{285}$ Against this wave of decolonialism, the Trusteeship System could not protect the territories under its care from "premature statehood." 286 This was noted in ironic form by the U.N. General Assembly when it terminated the Trusteeship Agreement for Ruanda-Urundi ${ }^{287}$ and then authorized U.S. $\$ 2,000,000$ " to ensure the continuation of essential services

277. PARKER, supra note 8, at 30. See generally Legal Consequences for States of the Continued Presence of South Africa in Namibia (South-West Africa) Notwithstanding Security Council Resolution 276, 1971 I.C.J 16, at 67 - 100 (June 21) (separate opinion of VicePresident Ammoun).

278. PARKER, supra note 8 , at 30.

279. Id.

280. See id.

281. Id.

282. See PARKER, supra note 8, at 30 (quoting International Status of South West Africa, 1950 I.C.J. 128, at 150 (July 11) (separate opinion of Sir Arnold McNair).

283. See id.

284. Ruth Gordon, Saving Failed States: Sometimes a Neocolonialist Notion, 12 AM. U.J. INT'L. \& POL'Y 903, 953 (1997).

285. See id.

286. See PARKER, supra note 8 , at 31 .

287. See Trusteeship, supra note 7 . Ruanda-Urundi became the modern day nations of Rwanda and Burundi. See id. 
in the two countries' at the very moment that they were supposedly now able 'to stand by themselves.",288

In the report An Agenda for Peace, U.N. Secretary-General Boutros Boutros-Ghali noted a new priority for the United Nations would be "postconflict peace-building."289 To pursue this goal, the Secretary-General stated the Security Council, under its Chapter VII powers "to maintain or restore international peace and security," was the U.N. organization of choice to lead in peace-building. ${ }^{290}$ This methodology can be termed 'Security Councilmandated Trusteeship Administrations.'291 The Trusteeship Council was given no role in the report. ${ }^{292}$ This section of this Note analyzes the challenges the Security Council has faced or attempted to resolve, and discusses whether the Trusteeship Council could have played a role.

\section{A) State Failure}

A failed state has been defined as "the total breakdown of a state without some other 'centrali[z]ed entity' emerging in its place to claim statehood." 293 The response of the international community so far has been to provide humanitarian aid, but they have not addressed the foundational reasons of a state's collapse. ${ }^{294}$

The United Nations response to Somalia as a failed state is noteworthy. In May 1993, the United Nations Operation In Somalia II (UNOSOM II), acting under the authority of Security Council Resolution 814 began the task of "enforced peace-building." 295 The purpose of UNOSOM II was to "help create the basic building blocks that would enable [a ruling transitional Somalian authority] to lead the country firmly back onto the road to recovery."296 Those building blocks were based on humanitarian, political, (1962)).

288. PARKER, supra note 8, at 31 (quoting G.A. Res. 1746 (XVI), U.N. GAOR, 16th Sess.,

289. An Agenda for Peace. Preventive Diplomacy, Peacemaking and Peace-Keeping; Report of the Secretary-General, U.N. Doc. A/47/277 - S/24111 at q5 (1992), available at http://www.un.org/Docs/SG/agpeace.html (last visited Mar. 6, 2004).

290. U.N. CHARTER art. 39. Article 39 fully reads, "The Security Council shall determine the existence of any threat to the peace, breach of the peace, or act of aggression and shall make recommendations, or decide what measures shall be taken in accordance with Articles 41 and 42, to maintain or restore international peace and security." Id. See also PARKER, supra note 8 , at 31 .

291. PARKER, supra note 8, at 37.

292. See id. at 31 .

293. Id.

294. See id.

295. Id. at 33. See generally PARKER, supra note 8, at 32-33.

296. Id. at 33 . 
and security grounds. ${ }^{297}$ Local warlords began attacks on UNOSOM II personnel and the security situation worsened. ${ }^{298}$

The security and political objectives of UNOSOM II were abandoned by summer $1994 .{ }^{299}$ Commentators have noted that a "principle reason[ ] that UNOSOM II failed was that it ultimately subordinated political imperatives to military objectives resulting in each development on the ground being met by a military rather than political response." 300 The principles of governance, not security, are an advantage of the Trusteeship approach. ${ }^{301}$

\section{B) Disintegrating States}

The artificial boundaries of a state often do not correspond with the different peoples and cultures living within that state. ${ }^{302}$ This has become a destabilizing force in Africa, Europe, and Asia, most notably with the Soviet Union and Yugoslavia, where as states break away, or attempt to break away, into smaller states whose boundaries more closely align themselves to a specific people. ${ }^{303}$

The history of the breakup of Yugoslavia after the Cold War is too extensive to go into detail in this Note. Suffice it to say, that the Kosovo $0^{304}$ situation is a continuance of a long series of civil wars within the region. ${ }^{305}$ The U.N. Security Council, on June 10, 1999, adopted Resolution 1244 creating a United Nations Interim Administration Mission in Kosovo (UNMIK). ${ }^{306}$ UNMIK's goal was to create the ability of the Kosovar Albanians "to exercise a degree of self-government within the framework of the Federal Republic of Yugoslavia." ${ }^{307}$ To eventually accomplish that goal, "the Secretary-General's Special Representative assumed 'all legislative and executive authority with respect to Kosovo." 308

Although this arrangement sounds somewhat like the international territorial administrations discussed earlier, UNMIK's goal was to create an autonomous Kosovo within the Federal Republic of Yugoslavia, despite the clearly expressed wishes of the population for independence. ${ }^{309}$ The Security

297. See id. at 32-33.

298. See id. at 33.

299. See id.

300. Id.

301. See PARKER, supra note 8, at 33.

302. See id. at 34.

303. See id.

304. See The Columbia Encyclopedia, 6th ed. (2001), at http://www.bartleby.com/65/ ko/Kosovo.html (last visited Mar. 6, 2004). Kosovo is a Serbian province with an ethnic population of approximately eighty percent Albanians. See id.

305. See PARKER, supra note 8, at 34.

306. See id.

307. Id.

308. Id.

309. See id. 
Council effectively ignored Article 1(2) of the U.N. Charter concerning "selfdetermination of peoples" ${ }^{310}$ in order to create a peace in an unstable region. ${ }^{311}$

No formal Trusteeship Agreement has been created between the States directly concerned and the United Nations, nor has any attempt been made by these States and authorities to raise the issue of the Trusteeship system; ${ }^{312}$ therefore, Kosovo is not a Trust Territory as defined by Articles $77^{313}$ and 78. ${ }^{314}$ It can be said that Resolution 1244 has created a "de facto trusteeship" that has the same goals of a true trusteeship: "peace and security, promotion of self-government, promotion of human rights and equal treatment." 315 Other commentators believe the arrangement in Kosovo is not worthy of the name 'trusteeship' because there is "an expectation that the Trustees will act in the best interests of their charges not in the best interests of the global status quo."316

\section{C) Disputed Territory}

East Timor ${ }^{317}$ had been a Portuguese possession until Indonesian forces seized it in 1975. ${ }^{318}$ After the population of East Timor voted for independence, pro-Indonesian militias sacked the territory and displaced hundreds of thousands of civilians. ${ }^{319}$ Subsequently order was restored and the U.N. Security Council passed Resolution 1272 to establish the United Nations Transitional Administration in East Timor (UNTAET). ${ }^{320}$ Some of the administrative acts UNTAET performed included reconstruction of infrastruc-

310. U.N. CHARTER art. 1. para. 2. It states that one of the purposes of the United Nations is " $[t]$ o develop friendly relations among nations based on respect for the principle of equal rights and self-determination of peoples, and to take other appropriate measures to strengthen universal peace." Id.

311. See PARKER, supra note 8, at 35.

312. See id.

313. See U.N. CHARTER art. 77(1). Article 77(2) states, "It will be a matter for subsequent agreement as to which territories in the foregoing categories will be brought under the trusteeship system and upon what terms." U.N. CHARTER art. 77(2).

314. See U.N. CHARTER art. 78. Article 78 states, "The trusteeship system shall not apply to territories which have become Members of the United Nations, relationship among which shall be based on respect for the principle of sovereign equality." Id.

315. See PARKER, supra note 8 , at 35.

316. Id. at 36.

317. See East Timor, supra note 11. East Timor occupies the eastern half of the island Timor located at the eastern end of the Indonesian archipelago in South East Asia. See id. East Timor is northwest of Australia. See id.

318. See id.

319. See Matheson, supra note 193 , at 81.

320. See id. at 82 . The U.N. Secutiry Council established UNTAET with the mission to assume overall administrative responsibility for East Timor and exercise executive and legislative authority. Id. 
ture, appointment and removal of judges and prosecutors, currency transactions, training of civil servants, and regulation of budgetary matters. ${ }^{321}$

UNTAET was more similar than its predecessors in fulfilling the role that would be expected of an Administering Authority under the disfavored Trusteeship System. ${ }^{322}$ Resolution 1272 did not ignore the expressed wishes of the East Timorese, their aspirations for self-government, and on May 20, 2002, East Timor became an independent state. ${ }^{323}$ "UNTAET can be said to have acted in the best interests of the East Timorese people as they themselves saw it." 324 The 'Security Council-mandated Trusteeship Administrations' had come of age; however, the Security Council was never designed for this function. ${ }^{325}$

\section{PART IV: LEGAL PROBLEMS WITH TRUSTEESHIP}

Two concepts pose significant obstacles to imposing trusteeships on states: sovereignty and self-determination. ${ }^{326}$ Part IV of this Note analyzes the legal obstacles and determines how the concept of a trusteeship can still be applied or modified to allow compliance with international law.

\section{A) The Sovereignty Problem}

"The trusteeship system shall not apply to territories which have become Members of the United Nations, relationship among which shall be based on respect for the principle of sovereign equality. ${ }^{327}$ On its face, such text seems "not to permit the imposition of trusteeship status on Member States," 328 like Iraq. However, "sovereignty is a relative notion that has varied over time and has adapted to new situations and exigencies . ..."329 During the history of the United Nations, the concept of sovereignty has changed and weakened due to an increased interdependence by states via trade, culture, telecommunications, human rights, and other matters. ${ }^{330}$ "Control of internal and external

321. See id.

322. See PARKER, supra note 8 , at 36 .

323. See id. East Timor is currently the world's newest democracy. See East Timor, supra note 11 .

324. PARKER, supra note 8 , at 37.

325. See id.

326. See Ruth Gordon, Some Legal Problems with Trusteeship, 28 CORNELLINT'LL.J. 301, 304 (1995).

327. U.N. CHARTER art. 78. Sovereign equality has been interpreted to mean "each State enjoys the rights inherent in full sovereignty; all States enjoy equal rights and duties as well as juridical equality ... . each State has the right freely to choose and develop its political, economic, and cultural systems . ..." Gordon, supra note 326, n62 (citing Hurst Hannum, Rethinking Self-Determination, 34 VA. J. INT'L L.1, 14(1993)).

328. Gordon, supra note 326, at 312.

329. Id. at 313-14.

330. See Id. at 314-15. 
affairs is the essence of sovereignty, and surrendering all power over these matters to another entity [such as in a trusteeship] is a relinquishment of sovereignty.",331

The results of the Iraq war may have simplified the complex issues of sovereignty in a trusteeship context. The question is now, once a country is invaded is it still sovereign? The answer is no. As the United States and United Kingdom are currently administering Iraq with the purpose to transfer sovereignty to the Iraqi people, ${ }^{332}$ it cannot be said that Iraq is fully sovereign within the meaning of Article 78 of the U.N. Charter. The sovereignty issue is not a legal obstacle for applying a trusteeship to Iraq due to their, the Iraqi people's, current lack of control over internal and external affairs at this time.

\section{B) A People's Self-Determination}

Would the creation of a trusteeship "infringe the right of an indigenous people of a territory to self-determination and to what extent[, if any, can] such an infringement . . . be considered permissible[?]"333

"The International Court of Justice has found that self-determination is a legal right specifically applicable to non-self-governing territories." ${ }^{334}$ Selfdetermination has an external component, "that is the right of [the] people to be free of foreign domination." 335 Self-determination also has an internal component, "the right of [the] people to assert its will against its own government." ${ }^{336}$ If self-determination means freedom from all forms of foreign control and independence, then a trusteeship, which implies dependence and tutelage under an Administering Authority, sounds conflicting to the principle at first glance. ${ }^{337}$

"Self-determination ... include[s] the right of a people freely to determine their own political status. While peoples have generally preferred independence when exercising that choice, it is feasible that they might choose a more or less benign form of outside control." ${ }^{338}$ This has occurred in a limited fashion for the International Territorial Administration of Cambodia

331. Id. at 316.

332. See generally Marina Ottaway \& Thomas Carothers, Policy Brief: The Right Road to Sovereignty in Iraq, CARNEGIE ENDOWMENT FOR INT'L PEACE, Feb. 15, 2004, available at http://www.ceip.org/files/publications/documents/Policybrief27_000.pdf (last visited Mar. 6, 2003).

333. PARKER, supra note 8 , at 41 .

334. Gordon, supra note 326, at 319-20. Concerning the right of self-determination to non-self-governing territories see Legal Consequences for States of the Continued Presence of South Africa in Namibia (South-West Africa) Notwithstanding Security Council Resolution 276, 1971 I.C.J 16 (June 21). See also, Western Sahara, 1975 I.C.J. 12 (Oct. 16).

335. PARKER, supra note 8 , at 42.

336. Id.

337. See Gordon, supra note 326 , at 321.

338. Id. at 322. 
as discussed in Part I(D)(iv) of this Note ${ }^{339}$ when the warring factions delegated certain duties, such as foreign affairs, finance, and defense to the United Nations Transitional Authority in Cambodia (UNTAC) ${ }^{340}$ If selfdetermination means to pay attention to the freely expressed will of the people, then the people could freely choose, under a democratic process, foreign supervision by an inter-governmental organization. ${ }^{341}$

The U.N. Charter does not appear to find conflict with the principles of trusteeship and self-determination. ${ }^{342}$ Article 76(b) states as one of the "basic objectives of the trusteeship system" 343 is to "promote . . progressive development towards self-government or independence ... [through] the freely expressed wishes of the peoples concerned."344 "It would therefore appear that as with the notion of sovereignty, in [the] Trusteeship Territories self-determination is a right held in suspension or abeyance until the Administering Authority can create the circumstances in which it can once more receive expression." 345

Such a standard was nearly articulated by the International Court of Justice in its Advisory Opinion on the Western Sahara. ${ }^{346}$

The validity of the principle of self-determination ... is not affected by the fact that in certain cases the General Assembly has dispensed with the requirement of consulting [with] the inhabitants of a given territory. Those instances were based ... on the conviction that a consultation was totally unnecessary, in view of special circumstances. ${ }^{347}$

The broad language of 'special circumstances' can easily cover the situations discussed by Party III of this Note. The Albanian inhabitants of Kosovo under Yugoslav leadership, the East Timorese under either Portuguese or Indonesian rule, nor the Somalians under a state of anarchy and civil war could "truly be said to have been enjoying self-determination prior to the involvement of the international community." 348

In summary, although the people of Non-Self-Governing Territories have a right to self-determination, that right may be held in suspension until conditions provided by an Administering Authority allow such right to be expressed.

339. See infra Part I (D)(iv).

340. See Matheson, supra note 193, at 77.

341. See Gordon, supra note 326 , at 322.

342. See PARKER, supra note 8 , at 42.

343. U.N. CHARTER art. 76.

344. U.N. CHARTER art. 76(b).

345. PARKER, supra note 8, at 42.

346. See id.

347. Western Sahara, 1975 I.C.J. 12 (Oct. 16), at $\mathbb{} 59$.

348. PARKER, supra note 8, at 43. 


\section{PART V: A NEW IRAQ WITH THE OLD TRUSTEESHIP COUNCIL}

Iraq is currently a land in transition. The March 2003 invasion, led by the United States, ended the regime of dictator Saddam Hussein. ${ }^{349}$ Though more control is slowly going back to the Iraqi people, Iraq is currently under the administration of the United States and United Kingdom as occupying powers. ${ }^{350}$ Certainly it is theoretically possible that the United States and United Kingdom can voluntarily call the Trusteeship Council back into meeting. The annual meetings were suspended by the Trusteeship Council after it discharged its last Trusteeship Agreement; however, the Council still exists due to the lethargy of the member states in rewriting the United Nations Charter which has prevented the abolition of the Trusteeship Council. ${ }^{351}$

The administering countries can invoke Article 77(1)(c) and voluntarily place the Iraqi territory, as a territory under their responsibility, under the Trusteeship System. ${ }^{352}$ This could have occurred between Portugal, Indonesia, concerning the pre-independent territory of East Timor. ${ }^{353}$ Several advantages do exist if Iraq were to be placed in the Trusteeship System. The purpose of the Trusteeship Council was to promote peace and security, encourage respect for human rights and equal treatment of people, and advance the economic, social, and political goals of the native people. ${ }^{354}$ These are all goals the United States and United Kingdom are pursuing that would add an air of international accountability that some commentators feel is lacking. ${ }^{355}$

As noted in Part III of this Note, the U.N. Security Council was not designed to perform these trusteeship-like tasks due to its focus on maintaining peace. ${ }^{356}$ Additionally, the Security Council has a veto power vested in the

349. See CIA - World Factbook - Iraq, at http://www.cia.gov/cia/publications/factbook/ geos/iz.html (last visited Mar. 6, 2004).

350. See S.C. Res. 1483, U.N. SCOR, U.N. Doc. S/RES/1483 (2003).

351. See PARKER, supra note 8, at 12. See also Kennedy, supra note 15. During the 1990 s there was serious discussion on using the Trusteeship Council in response to the number of failed states, such as Rwanda, Cambodia and Somalia, at that time; however, the idea stalled due to bureaucratic infighting and political objections. See id.

352. See U.N. CHARTER art. 77 para. 1(c).

353. See PARKER, supra note 8, at 43. After the citizens of East Timor voted in their popular consultation against future Indonesian rule, Portugal could have invoked Article 77 (1)(c) to establish a trusteeship agreeable to both Indonesia and Portugal with the U.N. acting as Administering Authority. See id.

354. See U.N. CHARTER art. 76.

355. See Pierre M. Atlas, Bold Policy Shifts Needed by U.S. in the Middle East, INDIANAPOLIS STAR, Sept. 22, 2003, at A10. See also David Hannay, The UN Must Have a Bigger Role in Iraq, FINANCIAL TIMES, July 15, 2003, available at http://www.globalpolicy.org/security/issues/iraq/after/2003/0715unrole.htm (last visited Mar. 6, 2004).

356. See PARKER, supra note 8 , at 37. 
Permanent Five that the Trusteeship Council lacks. ${ }^{357}$ As a result, the ability to veto turns the Security Council into "a more political animal where the domestic political concerns of its members often outweigh any other consideration[s]." 358

The Trusteeship Council has access to the other organs of the United Nations under Article $91 .^{359}$ Availability of as many resources as possible can only help the situation in Iraq. ${ }^{360}$ While access to those and other resources is in part a political question that is beyond the scope of this Note, the practical reality is that such concerns exist. ${ }^{361}$

Another practical concern is that some, perhaps many, countries will not assist in the rebuilding of Iraq unless the United Nations becomes more involved. ${ }^{362}$ Under a true Trusteeship System, the United Nations would obtain the ultimate supervisory authority; ${ }^{363}$ with the Administering Powers (the United States and United Kingdom already being recognized as "the Authority") having day to day control of the Trust Territory. ${ }^{364}$

As discussed in Part IV of this Note, the legal questions of sovereignty and self-determination are not insurmountable. ${ }^{365}$ It appears that under international law such legal issues are allowed to be held in abeyance by Administering Authorities when they are actively promoting the betterment of the people subject to the trust. ${ }^{366}$

357. Compare U.N. ChARTER art. 89 para. 2, "Decisions of the Trusteeship Council shall be made by a majority of the members present and voting." Id., with "Decisions of the Security Council on all other matters shall be made by an affirmative vote of nine members including the concurring votes of the permanent members." U.N.CHARTER art. 27 para. 3. (Emphasis added).

358. PARKER, supra note 8, at 50.

359. See U.N. CHARTER art. 91. "The Trusteeship Council shall, when appropriate, avail itself of the assistance of the Economic and Social Council and of the specialized agencies in regard to matters with which they are respectively concerned." U.N. CHARTER art. 91.

360. See Kennedy, supra note 15 . See also S. C. Res. 1483, U.N. SCOR, U.N. Doc. S/RES/1483 (2003).

361. See generally Jon Sawyer, Bush Faces Challenges in Gaining U.N. Support, INDIANAPOLIS STAR, Sept. 21, 2003, at A15. See also Atlas, supra note 355. See also Kennedy, supra note 15.

362. See Deutsche Welle, Poland Takes up Iraq Command as U.S. Looks for More Help (Aug. 3, 2003), available at http://www.dw-world.de/english/0,3367,7489_A_962158_1_ A,00.html (last visited Mar. 6, 2003). The story notes "India, Pakistan, Turkey among others have been loath to get involved unless the United Nations is given more authority in reconstruction efforts." Id. "Some potential troop contributors have refused to commit soldiers unless a multinational force is deployed under a U.N. umbrella." Edith M. Lederer, Resolution Offers U.N. Larger Role, INDIANAPOLIS STAR, Sept. 2, 2003, at A1.

363. See U.N. CHARTER art. 81.

364. See S. C. Res. 1483, U.N. SCOR, U.N. Doc. S/RES/1483 (2003).

365. See generally PARKER, supra note 8 , at $37-43$.

366. See id. at 42. 


\section{CONCLUSION}

The administration of other lands and peoples for their benefits has a long and well developed history. ${ }^{367}$ In the Twentieth Century, the utilization of the Mandates System by the League of Nations and the International Trusteeship Sytsem used by the United Nations, both set up formal programs to assist territories that were not capable of governing themselves for whatever reasons. ${ }^{368}$ The last of the Trusteeship Agreements under the U.N. Trusteeship Council expired in $1994 .{ }^{369}$ Although originally conceived to assist colonies towards self-determination of their fate, there are situations present today where a trusteeship relationship is conceived to assist peoples that desire some form of self-government. ${ }^{370}$

Iraq is a good candidate to be placed into a trusteeship arrangement as the people are not currently governing themselves due to the occupation after the war; and those people, along with the occupying powers, desire assistance from the outside world to promote the Iraqi people's self-interest. Although the Trusteeship Council has not been in use for nearly a decade now, it still exists with all its chartered legal powers. ${ }^{371}$ The initial legal concerns that a trusteeship would be incompatible with goals of sovereignty and selfdetermination are not as daunting after some analysis. ${ }^{372}$ The issue of sovereignty is bypassed due to a military occupation by the United States and United Kingdom thereby preventing the exercise of Iraqi sovereignty. ${ }^{373}$ An analysis of the U.N. Charter and several International Court of Justice cases demonstrates that a trusteeship can be utilized as a tool to further selfdetermination while holding the "right ... in suspension or abeyance until the Administering Authority can create the circumstances in which it can once more receive expression." 374

The purpose of the Trusteeship Council was to explicitly advance peoples toward a preferred form of self-governance. ${ }^{375}$ The Security Council, whose purpose is the maintenance and restoration of peace and security, ${ }^{376}$ has exhibited conflicting duties when imposing trusteeships in Somalia and

367. See generally PARKER, supra note 8.

368. See id. at 6-9.

369. See id. at 12 .

370. See generally id. See also Gordon, supra note 326. See also Matheson, supra note 193. See also Wilde, supra note 99.

371. See generally PARKER, supra note 8.

372. See id. at $37-43$.

373. See generally Ottaway \& Carothers, supra note 332. See also Atlas, supra note 355. An Islamic summit in Malaysia noted a desire to restore Iraqi sovereignty soon. See Patrick McDowell, Iraq Tops Agenda at Islamic Summit, InDIANAPOLIS STAR, Oct. 12, 2003, at A15.

374. PARKER, supra note 8 , at 42.

375. See U.N. CHARTER art. 76.

376. See id. at art. 24. 
Kosovo where security concerns dominated advancement issues. ${ }^{377}$ Also, any political wranglings of the members of the Trusteeship Council are easily resolvable with a simple majority vote. ${ }^{378}$ This differs from the Security Council, where one Permanent Member's veto power ${ }^{379}$ can result in gridlock and inaction. Finally, the use of the United Nations generally, specifically through the Trusteeship Council, could open the floodgates of international aid that the people of Iraq need. ${ }^{380}$

A revival of the United Nations Trusteeship Council, as well as placing Iraq within it, could be the win-win-win solution the United Nations, the United States, and the Iraqi people all desire.

377. See PARKER, supra note 8, at 30-36. See also Matheson, supra note 193.

378. See U.N. CHARTER art. 89 para. 2. "Decisions of the Trusteeship Council shall be made by a majority of the members present and voting." Id.

379. See U.N. ChARTER art. 27 para. 3. "Decisions of the Security Council on all other matters [those non-procedural] shall be made by an affirmative vote of nine members including the concurring votes of the permanent members ...."Id. The permanent members are the People's Republic of China, France, Russia, the United Kingdom, and the United States. See U.N. CHARTER art. 23 para. 1.

380. See generally Ottaway \& Carothers, supra note 332. See also Atlas, supra note 355. See also Hannay, supra note 355. See also Sawyer, supra note 361. See also Lederer, supra note 362 . 